\title{
Physico-chemical composition of native fruits of the Ceará coast at different development stages
}

\author{
Nigéria P. Gonçalves ${ }^{1}$, Eliseu M. P. de Lucena ${ }^{2}$, Oriel. H. Bonilla ${ }^{2}$ \& Francisca J. C. Tavares ${ }^{1}$ \\ ${ }^{1}$ Universidade Estadual do Ceará/Centro de Ciências e Tecnologia/Mestrado Acadêmico em Recursos Naturais. Fortaleza, CE. E-mail: nibotanica@gmail.com \\ (Corresponding author); jessika_te10@hotmail.com \\ ${ }^{2}$ Universidade Estadual do Ceará/Centro de Ciências da Saúde/Curso de Ciências Biológicas. Fortaleza, CE. E-mail: eliseu.lucena@uece.br; oriel.herrera@uece.br
}

\section{Key words:}

Byrsonima gardneriana

Chrisobalanus icaco

Eugenia punicifolia

Mouriri cearensis

\begin{abstract}
A B S T R A C T
This study aimed to evaluate the physico-chemical composition of native fruits of the Ceará coast at different development stages. The fruits of 'guajiru', 'manipuçá,' 'murici-pitanga' and 'murta' were collected during the year 2014, and the following evaluations were made: total soluble solids, total titratable acidity, $\mathrm{pH}$, total soluble solids and titratable acidity ratio. A completely randomized design was used, with 5 or 6 treatments, depending on the maturation stage and 4 replicates. For total soluble solids, 'murta' obtained a minimum of $2.6^{\circ}$ Brix in stage 1 and 'manipuçá obtained maximum of $24.53^{\circ}$ Brix in stage 5 . For the total titratable acidity, 'guajiru' showed minimum of $0.09 \%$ in stages 3 and 4 , and 'murici-pitanga' showed maximum of $3.29 \%$ in stage 6. 'Murici-pitanga' had minimum pH of 3.44 in stage 5 and 'guajiru', maximum $\mathrm{pH}$ of 5.9 in stage 2 . For total soluble solids and titratable acidity ratio, 'murici-pitanga' exhibited a minimum of 3.25 in stages 1 and 3, and 'guajiru' showed maximum of 141.11 in stage 4 . It was concluded that 'guajiru' and 'manipuçá' fruits reached physiological maturity in stage 3, whereas 'murici-pitanga' and 'murta' fruits reached in stage 4 ; thus, these are the ideal stages for fruit harvest.
\end{abstract}

\section{Palavras-chave: Byrsonima gardneriana Chrisobalanus icaco Eugenia punicifolia Mouriri cearensis}

\section{Composição físico-química de frutas nativas do litoral cearense em diferentes estádios de desenvolvimento}

\section{R E S U M O}

Objetivou-se, com este trabalho, avaliar a composição físico-química de frutas nativas do litoral cearense em diferentes estádios de desenvolvimento. Os frutos de guajiru, manipuçá, murici-pitanga e murta, foram colhidos durante o ano de 2014, através das seguintes avaliações: sólidos solúveis totais, acidez total titulável, $\mathrm{pH}$ e relação sólidos solúveis totais e acidez total titulável. Utilizou-se o delineamento inteiramente casualizado com 5 ou 6 tratamentos, dependendo do estádio de maturação do fruto e 4 repetições. Para sólidos solúveis totais a murta obteve mínimo de 2,6 ${ }^{\circ}$ Brix no estádio 1 e o manipuçá obteve máximo de 24,53 Brix no estádio 5 . Na acidez total titulável, o guajiru com mínimo de 0,09\% nos estádios 3 e 4, e o murici-pitanga com máximo de 3,29\% no estádio 6. Para o pH no murici-pitanga foi obtido mínimo de 3,44 no estádio 5 e o guajiru, máximo de 5,9 no estádio 2. Para a relação sólidos solúveis totais e acidez total titulável, o murici-pitanga com mínimo de 3,25 nos estádios 1 e 3 e o guajiru com máximo de 141,11 no estádio 4 . Concluiu-se que os frutos do guajiru e do manipuçá atingiram a maturidade fisiológica no estádio 3; já os frutos do murici-pitanga e da murta os atingiram no estádio 4; portanto, esses são os estádios ideais para a colheita dos frutos. 


\section{INTRODUCTION}

Fruit appearance is one of the criteria most used by the consumers to evaluate fruit quality (Krause et al., 2012). A fruit is considered as of quality when it meets the expectations of the different consumer segments, in its internal and external characteristics, the internal ones related to the taste (soluble solids and acidity) and juice content (yield), and the external ones related to the good appearance (skin color, size, weight, absence of defects of the fruits), meeting the standards to achieve the quality desired in the markets (Ocampo et al., 2013).

Due to the commercial opening, the global fruit market has become more competitive and prone to novelties, such as native and exotic fruits, especially with the media's publicity on the beneficial effects of fruit consumption, highlighting them as healthy, balanced, functional and diversified foods, with their colors, shapes, smells and tastes, which aroused in the consumers the desire for native and exotic fruits (Silva et al., 2011).

Fruit harvest in adequate maturation stages is a determinant factor for the maintenance of post-harvest quality. Fruits harvested early do not have the ability to develop the complete ripening, damaging their final quality (Drehmer \& Amarante, 2008).

In this context, the present research aimed to evaluate the physico-chemical composition of four fruits native to the Ceará coast in different development stages, 'guajiru' (Chrisobalanus icaco L.), 'manipuçá' (Mouriri cearensis Huber), 'muricipitanga' (Byrsonima gardneriana A. Juss.) and 'murta' (Eugenia punicifolia (Kunth) DC.), to define the ideal harvest point.

\section{Material AND Methods}

The study was carried out at the Laboratory of Plant Ecophysiology, of the State University of Ceará - UECE, in Fortaleza-CE, Brazil, during the year 2014.

The exsiccates of the species 'guajiru' - Chrysobalanus icaco L. (57408), 'manipuçá' - Mouriri cearensis Huber (57407), 'murici-pitanga' - Byrsonima gardneriana A. Juss. (57409) and 'murta' - Eugenia punicifolia (Kunth) DC. (57410) are deposited in the Prisco Bezerra Herbarium, at the Federal University of Ceará - UFC, in Fortaleza-CE, Brazil.

'Murta' fruits were collected at the Ceará State Botanical Park, in Caucaia-CE, at the coordinates $3^{\circ} 44^{\prime} 10^{\prime \prime} \mathrm{S}$ and $38^{\circ}$ 39' 11" W, constituted of Restinga, Caatinga and Mangrove, with minimum rainfall from August to October $(0 \mathrm{~mm})$ and maximum in May (157.4 mm) (FUNCEME, 2015; IPECE, 2015), under Equatorial Savanna climate with dry summer (As), according to the climatic classification of Köppen-Geiger (Kottek et al., 2006).

'Guajiru', 'manipuçá' and 'murici-pitanga' fruits were harvested at the Botanical Garden of São Gonçalo, in São Gonçalo do Amarante-CE, located between the coordinates $3^{\circ} 36^{\prime} 26^{\prime \prime} \mathrm{S}$ and $38^{\circ} 58^{\prime} 06^{\prime \prime} \mathrm{W}$, constituted of Restinga, with minimum rainfall in August $(1.5 \mathrm{~mm})$ and maximum in April (281.8 mm) (FUNCEME, 2015; IPECE, 2015), under
Equatorial Savana climate with dry summer (As) according to the climatic classification of Köppen-Geiger (Kottek et al., 2006).

The fruits of the four species native to the Ceará coast were manually and randomly harvested from 10 previously selected mother plants of each species, approximately $2.5 \mathrm{~kg}$ of fruits per maturation stage. 'Guajiru' and 'manipuçá were characterized in five maturation stages $(\mathrm{E})$ ( $\mathrm{E}_{1}$-very unripe, $\mathrm{E}_{2}$-unripe, $\mathrm{E}_{3}$ early ripe, $\mathrm{E}_{4}$-fully ripe and $\mathrm{E}_{5}$-senescent) according to the skin color, while 'murici-pitanga' and 'murta' were characterized in six maturation stages ( $\mathrm{E}_{1}$-very unripe, $\mathrm{E}_{2}$-moderately unripe, $\mathrm{E}_{3}$-unripe, $\mathrm{E}_{4}$-early ripe, $\mathrm{E}_{5}$-fully ripe and $\mathrm{E}_{6}$-senescent).

In the fruits, the maturation stages varied according to the skin color as follows: 'guajiru'-100\% light green $\left(E_{1}\right), 75 \%$ light green and $25 \%$ purple $\left(\mathrm{E}_{2}\right), 50 \%$ light green and $50 \%$ purple $\left(\mathrm{E}_{3}\right), 90 \%$ purple and $10 \%$ yellow $\left(\mathrm{E}_{4}\right)$ and $100 \%$ purple $\left(\mathrm{E}_{5}\right)$; 'manipuçá'-100\% dark green $\left(\mathrm{E}_{1}\right), 100 \%$ light green $\left(\mathrm{E}_{2}\right), 75 \%$ light green and $25 \%$ orange $\left(E_{3}\right), 90 \%$ orange and $10 \%$ light green $\left(\mathrm{E}_{4}\right)$ and $100 \%$ orange $\left(\mathrm{E}_{5}\right)$; 'murici-pitanga'-100\% dark green $\left(E_{1}\right), 100 \%$ light green $\left(E_{2}\right), 50 \%$ light green and $50 \%$ orange $\left(\mathrm{E}_{3}\right), 75 \%$ orange and $25 \%$ light green $\left(\mathrm{E}_{4}\right), 100 \%$ orange $\left(\mathrm{E}_{5}\right), 100 \%$ red $\left(\mathrm{E}_{6}\right)$; 'murta' $-100 \%$ dark green $\left(\mathrm{E}_{1}\right), 50 \%$ light green and $50 \%$ yellow $\left(\mathrm{E}_{2}\right), 75 \%$ orange and $25 \%$ yellow $\left(\mathrm{E}_{3}\right)$, $100 \%$ orange $\left(\mathrm{E}_{4}\right), 100 \%$ light red $\left(\mathrm{E}_{5}\right)$ and $100 \%$ dark red $\left(\mathrm{E}_{6}\right)$.

Initially, seeds were removed from the fruits and the pulp was processed in a domestic centrifuge and frozen in a freezer at $-20{ }^{\circ} \mathrm{C} \pm 1$, for later analysis of total soluble solids (TSS), total titratable acidity (TTA), $\mathrm{pH}$ and TSS/TTA ratio (SAR).

The TSS content was determined using a digital refractometer Reichert, $\mathrm{r}^{2}$ mini model, with scale from 0 to 45 'Brix, with automatic temperature compensation (IAL, 2008).

TTA was determined through titration with $\mathrm{NaOH}$ solution $(0.1 \mathrm{~N})$ until the end point. The results were expressed in percentage of citric acid, in the fresh matter (IAL, 2008).

The $\mathrm{pH}$ was measured in a digital $\mathrm{pH}$ meter with glassmembrane electrode (IAL, 2008).

TSS/TTA ratio was obtained through the quotient between both variables (IAL, 2008). The experimental design was completely randomized, with five treatments for 'guajiru' and 'manipuçá' or six for 'murici-pitanga' and 'murta', depending on the fruit maturation stages, and four replicates composed of 200 fruits each. The results were subjected to analysis of variance, observing the significance by $\mathrm{F}$ test and, when significant, Tukey test at 0.05 probability level was applied using the program Sistema para Análises Estatísticas $<$ V.1.0 $>$ ESTAT. Linear correlations between the variables were verified based on the significance by t-test, using the statistical program Assistat 7.7 (Silva \& Azevedo, 2016).

\section{Results AND Discussion}

According to Figure 1A, the total soluble solids (TSS) in 'guajiru' fruits had minimum value of $3.47^{\circ}$ Brix in $\mathrm{E}_{1}$ and maximum of $14.43{ }^{\circ}$ Brix in $\mathrm{E}_{5}$, respectively; in 'manipuçá' fruits, the minimum was $13.33^{\circ} \mathrm{Brix}$ in $\mathrm{E}_{3}$ and maximum was $24.53^{\circ}$ Brix in $\mathrm{E}_{5}$; in 'murici-pitanga', minimum of $5.73^{\circ} \mathrm{Brix}$ in $\mathrm{E}_{1}$ and maximum of $17.33^{\circ} \mathrm{Brix}$ in $\mathrm{E}_{6}$; in 'murta' fruits, 
A.

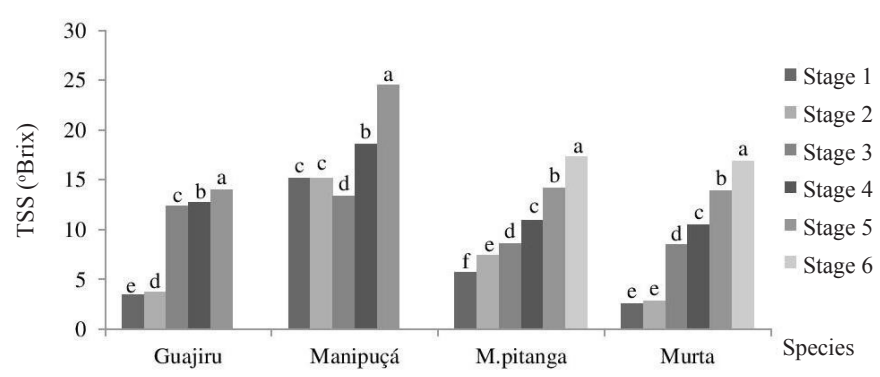

C.

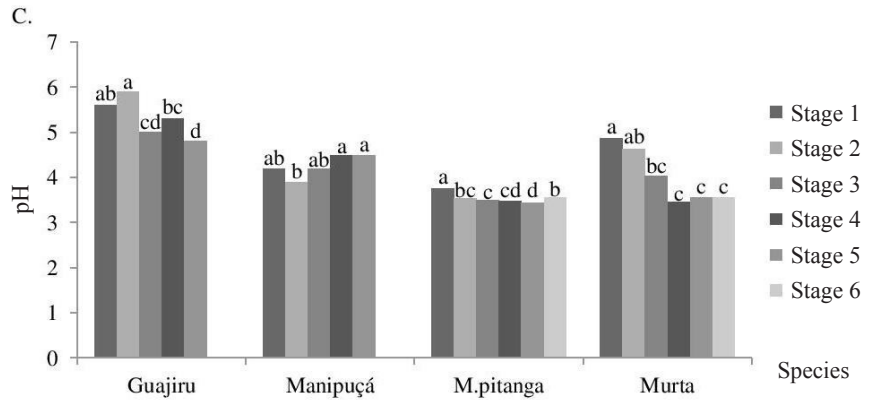

B.

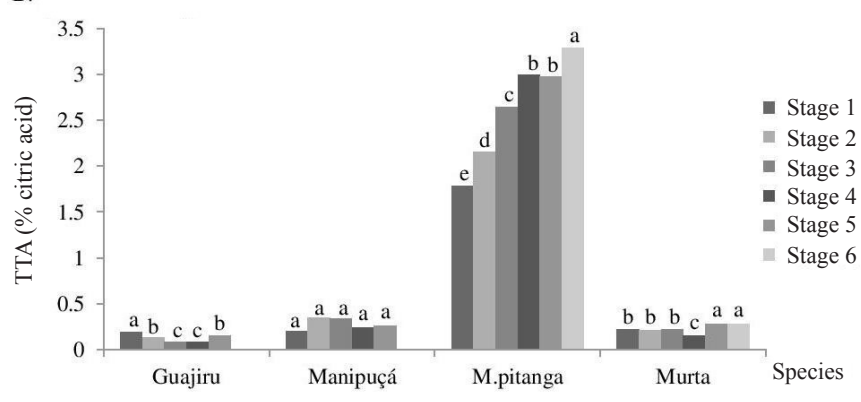

D.

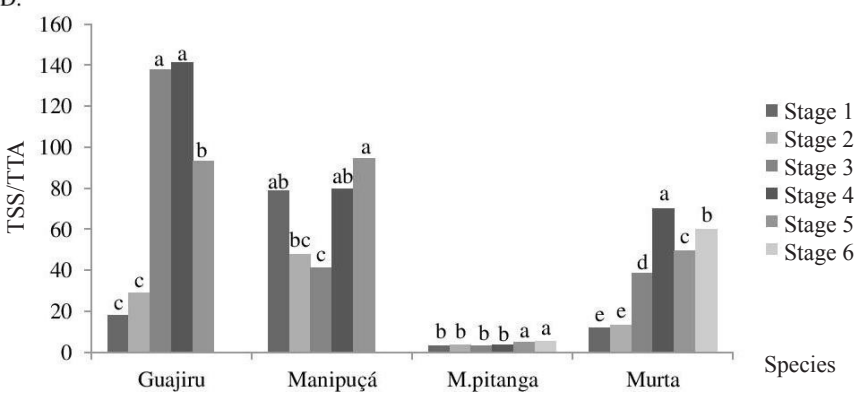

Means followed by the same letter in the same species do not differ by Tukey test at 0.05 probability level

Figure 1. Physical and chemical changes during the maturation of four fruits native to the Ceará coast: (A) Total soluble solids (TSS), (B) Total titratable acidity (TTA), (C) pH, (D) TSS/TTA ratio (SAR)

minimum of $2.6^{\circ}$ Brix in $\mathrm{E}_{1}$ and maximum of $16.87^{\circ}$ Brix in $\mathrm{E}_{6}$. Hence, the TSS increased with the advancement of maturation.

Aguiar et al. (2011), studying 'guajiru' fruits (Chrysobalanus icaco L.), observed value of $10^{\circ} \mathrm{Brix}$, which is lower than that obtained in the fully ripe 'guajiru' fruit of the present study $\left(\mathrm{E}_{4}-12.7^{\circ} \mathrm{Brix}\right)$; thus, this difference indicates that the fruits of the present study are riper.

Garcia et al. (2011), evaluating 'manipuçá' fruits (Mouriri cearensis Huber) from São Gonçalo do Amarante-CE, obtained $15.41^{\circ}$ Brix in $\mathrm{E}_{1}$ and $16.75^{\circ}$ Brix in $\mathrm{E}_{5}$; therefore, the TSS in $\mathrm{E}_{1}$ are similar to that of 'manipuçá' (Mouriri cearensis Huber) in the present research $\left(E_{1}-15.13\right)$, but inferior to that in $E_{5}(24.53$ ${ }^{\circ}$ Brix). This difference can be attributed to the more advanced stage of senescence of the fruits in $\mathrm{E}_{5}$ studied by Garcia et al. (2011), since for the physico-chemical analysis of the fruits there was a longer lapse of time.

Silveira et al. (2014), analysing the TSS of 15 genotypes of "coroa de frade" puçá (Mouriri elliptica Mart.), obtained minimum of $21.90{ }^{\circ}$ Brix for the genotype 4 and maximum of 29.73, 20.00 and $28.67^{\circ}$ Brix, respectively, for the genotypes 13, E1 and 14; therefore, the above results were higher than those of fully ripe 'manipuçá' fruit of the present research $\left(\mathrm{E}_{4}-17.53{ }^{\circ} \mathrm{Brix}\right)$. Such superiority can be a consequence of the comparison of different species and the large genotypic variability.

Batista et al. (2015), studying some tropical fruits produced in the Sub-Medium São Francisco Valley, including 4 varieties of 'acerola' (Malpighia emarginata DC.), ripe, point out the following cultivars for TSS: the cultivar 'Sertaneja' showed lower TSS content, $7.3^{\circ} \mathrm{Brix}$, and the cultivar 'Okinawa' showed higher TSS content, $8.7^{\circ}$ Brix; thus, the reported values were inferior to those of fully ripe 'murici-pitanga' fruits, observed in the present study $\left(\mathrm{E}_{5}-14.2^{\circ} \mathrm{Brix}\right)$. Despite belonging to the same botanical family (Malpighiaceae), they are different species, thus justifying the observed difference in TSS.
According to Figure $1 \mathrm{~B}$, the analyzed fruits showed small variation in total titratable acidity (TTA), except 'muricipitanga': in 'guajiru' fruits, minimum of $0.09 \%$ in $\mathrm{E}_{3}$ and $\mathrm{E}_{4}$, and maximum of $0.19 \%$ in $\mathrm{E}_{1}$; in 'manipuçá' fruits, minimum of $0.20 \%$ in $\mathrm{E}_{1}$ and maximum of $0.35 \%$ in $\mathrm{E}_{2}$; in 'murici-pitanga' fruits, minimum of $1.78 \%$ in $\mathrm{E}_{1}$ and maximum of $3.29 \%$ in $\mathrm{E}_{6}$, while in 'murta' fruits, minimum of $0.15 \%$ in $\mathrm{E}_{4}$ and maximum of $0.28 \%$ in $\mathrm{E}_{5}$ and $\mathrm{E}_{6}$. Hence, TTA was increasing for 'muricipitanga' and 'murta', decreasing for 'guajiru', and constant for 'manipuçá with the advancement of maturation.

Aguiar et al. (2011), studying ripe fruits of 'guajiru' (Chrysobalanus icaco L.), obtained TTA value of $0.55 \%$, which is 6 times higher than that obtained in the fully ripe 'guajiru' fruit in the present research $\left(\mathrm{E}_{4}-0.09 \%\right)$. It is important to point out that the physico-chemical composition of 'guajiru' presented by Aguiar et al. (2011) refers to fruits from Arraial do Cabo-RJ, and for this reason differences are common, since the characteristics of temperature and composition of the soil, among others, interfere with the composition of the fruits.

Silveira et al. (2014) obtained, in "coroa de frade" puçá fruits from Beberibe-CE, mean TTA of $0.43 \%$ in the ripe stage, which is superior to those of fully ripe 'manipuçá' fruits obtained in the present study $\left(\mathrm{E}_{4}-0.24 \%\right)$. This discrepancy is due to the fact they are different species, despite being of the same genus (Mouriri).

The $\mathrm{pH}$ of the studied fruits showed variations along the maturation stages (Figure 1C). In 'guajiru' fruits, the minimum value was 4.8 in $\mathrm{E}_{5}$ and maximum value was 5.9 in $\mathrm{E}_{2}$; in 'manipuçá' fruits, the minimum was 3.9 in $\mathrm{E}_{2}$ and maximum was 4.5 in $\mathrm{E}_{4}$ and $\mathrm{E}_{5}$; in 'murici-pitanga', the minimum value occurred in $\mathrm{E}_{5}$ with mean of 3.44 and maximum of 3.75 in $\mathrm{E}_{1}$; in 'murta' fruits, minimum of 3.46 in $\mathrm{E}_{4}$ and maximum of 4.86 in $\mathrm{E}_{1}$. Therefore, $\mathrm{pH}$ was decreasing for 'guajiru', 'murici-pitanga' and 'murta'; however, it was increasing for 'manipuçá with the advancement of maturation. 
Aguiar et al. (2011), studying the $\mathrm{pH}$ of ripe 'guajiru' fruits (Chrysobalanus icaco L.), obtained value of 5.64, which is similar to that obtained in the fully ripe 'guajiru' fruit in the present study $\left(\mathrm{E}_{4}-5.3\right)$.

Silveira et al. (2014), analyzing the $\mathrm{pH}$ of 15 genotypes of ripe fruits of "coroa de frade" puçá, found a mean value of 4.53 , a result that is similar to that of the fully ripe 'manipuçá' fruit in the present research $\left(\mathrm{E}_{4}-4.50\right)$, which confirms this study.

Canuto et al. (2010), studying the $\mathrm{pH}$ of pulps of early ripe fruits from the Amazon, including 'araçá-boi' (Eugenia stipitata McVaugh), obtained value of 4.0, thus higher than that obtained in 'murta' fruits $\left(\mathrm{E}_{4}-3.46\right)$. In 'murici' fruits (Byrsonima crassifolia (L.) Kunth), the above-mentioned authors obtained value of 3.7 , which is higher than that obtained in 'murici-pitanga' fruits $\left(\mathrm{E}_{4}-3.48\right)$ in the present study. Although the compared species are in the same genus, this divergence is mainly attributed to the environmental difference of the studied ecosystems, i.e., Amazon Forest and Restinga.

For the TSS/TTA ratio (SAR) in 'guajiru' fruits, the minimum value (18.25) occurred in $\mathrm{E}_{1}$ and maximum (141.11) in $\mathrm{E}_{4}$; in 'manipuçá' fruits, minimum of 48 in $\mathrm{E}_{2}$ and maximum of 94.36 in $\mathrm{E}_{5}$; in 'murici-pitanga' fruits, minimum of 3.25 in $\mathrm{E}_{1}$ and $\mathrm{E}_{3}$, and maximum of 5.27 in $\mathrm{E}_{6}$; in 'murta' fruits, minimum of 11.82 in $\mathrm{E}_{1}$ and maximum of 60.24 in $\mathrm{E}_{6}$ (Figure 1D). Thus, SAR was increasing for 'guajiru', 'murici-pitanga' and 'murta', and decreasing for 'manipuçá' until the stage 3 , then it started to increase with the advancement of maturation.

Rufino et al. (2010) evaluated 18 non-traditional, ripe tropical fruits and, among the studied species of the Myrtaceae family, observed the following SAR values: 2.46 in 'camu-camu' (Myrciaria dubia (Kunth) McVaugh); 3.26 in 'uvaia' (Eugenia pyriformis Cambess.) and 32.60 in 'murta' (Blepharocalyx salicifolius (Kunth) O.Berg); the results were inferior to those of fully ripe 'murta' fruits in the present study $\left(\mathrm{E}_{5}-49.64\right)$. Although the compared species are in the same family, there is difference because all of them are from different sites (Belém, PA; Paraipaba, CE; Crato, CE; and Caucaia, CE, respectively) and species.

Silveira et al. (2014), analysing 15 genotypes of ripe "coroa de frade" puçá fruits, obtained minimum of 40.70 in the genotype 6 and maximum of 95.05 in the genotype 8 for SAR. Thus, the minimum value is inferior to those of fully ripe 'manipuçá' fruits of the present research $\left(\mathrm{E}_{4}-75.10\right)$ and the maximum value is superior to those of the studied 'manipuçá. As already mentioned before, these results are conflicting because the compared species are different.

Souza et al. (2014), studying 3 clones of 'acerola', obtained the following minimum and maximum values of SAR in four maturation stages (I, II, III and IV): cultivar 'Florida Sweet' ( $\mathrm{E}_{\mathrm{I}}-7.80$ and $\left.\mathrm{E}_{\mathrm{IV}}-15.42\right)$, cultivar 'Flor Branca' $\left(\mathrm{E}_{\mathrm{I}}-4.78\right.$ and $\mathrm{E}_{\mathrm{IV}}$ 6.99) and cultivar 'BRS 366' ( $\mathrm{E}_{\mathrm{I}}-4.56$ and $\left.\mathrm{E}_{\mathrm{IV}}-5.98\right)$. Therefore, the above-mentioned values were superior to those obtained in the 'murici-pitanga' fruit in the present study, for the initial and final stages $\left(\mathrm{E}_{1}-3.25\right.$ and $\left.\mathrm{E}_{6}-5.27\right)$. The differences between the contents found by Souza et al. (2014) and those of this experiment can be attributed to the differences between the species and location of the plants in different climates and soils.
The correlations between TSS, TTA, pH and SAR of the studied fruits are presented in Table 1. For 'guajiru', there were no significant correlations between the analysed variables; there was negative and significant correlation at 0.05 probability level between the variables TTA and SAR in 'manipuçá' fruits, with $\mathrm{r}=-0.96^{*}$. In 'murici-pitanga' fruits, there was negative correlation significant at 0.01 probability level between the variables TSS and TTA, and between the variables TTA and SAR, with $r=-0.99^{* *}$, as well as positive and significant correlation at 0.01 between the variables TSS and SAR, with $r=0.99^{* *}$. For 'murta', there were no significant correlations between the analysed variables.

Silveira (2008) observed correlation between 15 genotypes of "coroa de frade" puçá fruits and obtained negative and significant correlation at 0.01 probability level between the variables TTA and SAR, with $r=-0.95^{\star *}$. This result corroborates with those of the present research, because 'manipuçá' fruits (Mouriri cearensis Huber) also showed negative and significant correlation $\left(\mathrm{r}=-0.60^{\star}\right)$.

Lucena et al. (2011) obtained negative and significant correlation at 0.01 probability level in "Tommy Atkins" mango fruits between the variables TSS and TTA, with $\mathrm{r}=-0.74^{\star *}$; and TTA and SAR, with $r=-0.79^{* *}$, and positive and significant correlation between the variables TSS and SAR, with $r=0.93^{* *}$. The above-mentioned results corroborate with those of the present study, because in 'murici-pitanga' the obtained correlations were $r=-0.99^{\star *}, r=-0.99^{* *}$ and $r=0.99^{* *}$, respectively.

Table 1. Correlation ( $r$ ) matrix between total soluble solids (TSS), total titratable acidity (TTA), $\mathrm{pH}$ and TSS/TTA ratio (SAR) of fruits of 'guajiru', 'manipuçá', 'murici-pitanga' and 'murta' during maturation

\begin{tabular}{lccc}
\hline \multicolumn{1}{c}{ Variables } & TTA & pH & SAR \\
'Guajiru' & & & \\
TSS & $-0.60^{\text {ns }}$ & $0.27^{\text {ns }}$ & $0.89^{\text {ns }}$ \\
TTA & - & $-0.64^{\text {ns }}$ & $-0.10^{\text {ns }}$ \\
pH & - & - & $-0.06^{n s}$ \\
\hline 'Manipuçá' & & & \\
TSS & $0.47^{\text {ns }}$ & $-0.10^{\text {ns }}$ & $-0.34^{\text {ns }}$ \\
TTA & - & $0.37^{\text {ns }}$ & $-0.96^{*}$ \\
pH & - & - & $-0.61^{1 \mathrm{~ns}}$ \\
\hline 'Murici-pitanga' & - & & \\
TSS & $-0.99^{* *}$ & $-0.12^{\text {ns }}$ & $0.99^{* *}$ \\
TTA & - & $0.00^{\text {ns }}$ & $-0.99^{* *}$ \\
pH & - & - & $-0.13^{\text {ns }}$ \\
\hline 'Murta' & - & & \\
TSS & $-0.52^{\text {ns }}$ & $0.42^{\text {ns }}$ & $0.92^{\text {ns }}$ \\
TTA & - & $0.09^{\text {ns }}$ & $-0.62^{\text {ns }}$ \\
pH & - & - & $0.05^{\text {ns }}$ \\
\hline$*$ *** & & &
\end{tabular}

\section{Conclusions}

1. Total soluble solids were the variable that best stratified the maturation stages of the studied fruits, because 'guajiru', 'manipuçá', 'murici-pitanga' and 'murta' stratified in the stages $5,4,6$ and 5, respectively.

2. 'Guajiru' and 'manipuçá' fruits reached physiological maturation in the stage 3, while 'murici-pitanga' and 'murta' reached it in the stage 4 ; thus, these are the ideal stages for fruit harvest. 


\section{ACKNOWLedgments}

To the Ceará Foundation of Support to Scientific and Technological Development (FUNCAP), for granting the Master's scholarship to the first author; to the National Council for Scientific and Technological Development (CNPq) and Bank of Northeast Brazil (BNB), for the financial support to the research project.

\section{Literature Cited}

Aguiar, T. M. de; Sabaa-Srur, A. U. de O.; Samico, G. F. Potencial nutritivo e características físicas e químicas do abajeru. Pesquisa Agropecuária Tropical, v.41, p.102-109, 2011. https://doi. org/10.5216/pat.v41i1.9623

Batista, P. F.; Lima, M. A. C. de; Trindade, D. C. G. da; Alves, R. E. Quality of different tropical fruit cultivars produced in the lower basin of the São Francisco Valley. Revista Ciência Agronômica, v.46, p.176-184, 2015. https://doi.org/10.1590/ S1806-66902015000100021

Canuto, G. A. B.; Xavier, A. A. O.; Neves, L. C.; Benassi, M. de T. Caracterização físico-química de polpas de frutos da Amazônia e sua correlação com a atividade anti-radical livre. Revista Brasileira de Fruticultura, v.32, p.1196-1205, 2010. https://doi.org/10.1590/ S0100-29452010005000122

Drehmer, A. M. F.; Amarante, C. V. T. do. Conservação póscolheita de frutos de araçá-vermelho em função do estádio de maturação e temperatura de armazenamento. Revista Brasileira de Fruticultura, v.30, p.322-326, 2008. https://doi.org/10.1590/ S0100-29452008000200009

FUNCEME - Fundação Cearense de Meteorologia e Recursos Hídricos. Disponível em: <http://www.funceme.br/app/ calendario/produto/municipios/maxima/diario?data=2015-2-3>. Acesso: 25 Jan. 2015.

Garcia, R. C. G.; Gomes, J. P.; Lucena, E. M. P. de; Alves, N. M. C.; Santos, D. da C.; Oliveira, E. N. A. de. Parâmetros físico-químicos dos frutos de manipuçá em cinco estádios de maturação. Revista Educação Agrícola Superior, v.26, p.109-112, 2011.

IAL - Instituto Adolfo Lutz. Métodos físico-químicos para análise de alimentos. 4.ed. São Paulo: IAL, 2008. 1020p.

IPECE - Instituto de Pesquisa e Estratégia Econômica do Ceará. Disponível em: <http://www.ipece.ce.gov.br/publicacoes/perfil_ basico/index_perfil_basico.htm>. Acesso: 25 Jan. 2015.
Kottek, M.; Grieser, J.; Beck, C.; Rudolf, B.; Rubel, F. World map of Köppen-Geiger climate classification updated. Meteorologische Zeitschrift, v.15, p.259-263, 2006. https://doi.org/10.1127/09412948/2006/0130

Krause, W.; Neves, L. G.; Viana, A. P.; Araújo, C. A. T.; Faleiro, F. G. Produtividade e qualidade de frutos de cultivares de maracujazeiro-amarelo com ou sem polinização artificial. Pesquisa Agropecuária Brasileira, v.47, p.1737-1742, 2012. https:// doi.org/10.1590/S0100-204X2012001200009

Lucena, E. M. P. de; Assis, J. S. de; Alves, R. E.; Enéas Filho, J. Alterações físicas e químicas durante o crescimento e desenvolvimento de mangas 'Tommy Atkins' produzidas no Vale do São Francisco, Brasil. Journal Interamerican Society for Tropical Horticulture, v.53, p.48-51, 2011.

Ocampo, J.; Urrea, R.; Wyckhuys, K.; Salazar, M. Exploración de la variabilidad genética del maracuyá (Passiflora edulis f. flavicarpa Degener) como base para un programa de fitomejoramiento en Colombia. Acta Agronómica, v.62, p.352-360, 2013.

Rufino, M. do S. M.; Alves, R. E.; Brito, E. S. de; Pérez-Jiménez, J.; Saura-Calixto, F.; Mancini-Filho, J. Bioactive compounds and antioxidant capacities of 18 non-traditional tropical fruits from Brazil. Food Chemistry, v.121, p.996-1002, 2010. https://doi. org/10.1016/j.foodchem.2010.01.037

Silva, F. de A. S. e; Azevedo, C. A. V. de. The Assistat Software Version 7.7 and its use in the analysis of experimental data. African Journal of Agricultural Research, v.11, p.3733-3740, 2016. https://doi. org/10.5897/AJAR2016.11522

Silva, J. A. A. da; Grizotto, R. K.; Miguel, F. B.; Bárbaro, I. M. Caracterização físico-química de frutos de clones de doviális (Dovyalis abyssinica Warb). Revista Brasileira de Fruticultura, v.33, p.466-472, 2011. https://doi.org/10.1590/ S0100-29452011000500062

Silveira, M. R. S. Qualidade e atividade antioxidante de frutos de genótipos de puçazeiro "Coroa de Frade" (Mouriri elliptica Mart.) da vegetação litorânea do Ceará. Fortaleza: UFC, 2008. 117p. Dissertação Mestrado

Silveira, M. R. S. da; Alves, R. A.; Aragão, F. A. S. de; Figueiredo, R. W. de; Freitas, S. L. de A. Estudo de genótipos de puçá 'coroa de frade' da vegetação litorânea de Beberibe-CE. Revista Caatinga, v.27, p.159, 2014.

Souza, K. O. de; Moura, C. F. H.; Brito, E. S. de; Miranda, M. R. A. de. Antioxidant compounds and total antioxidant activity in fruits of acerola from cv. Flor Branca, Florida Sweet and BRS 366. Revista Brasileira de Fruticultura, v.36, p.294-304, 2014. https:// doi.org/10.1590/0100-2945-410/13 